\title{
Mutilating predation in the Cheirodontinae Odontostilbe pequira (Characiformes: Characidae)
}

\author{
Monise R. L. Lima ${ }^{1}$, Eduardo Bessa ${ }^{1,2}$, Diones Krinski ${ }^{3}$ and Lucélia Nobre Carvalho ${ }^{4}$
}

We observed individuals of Odontostilbe pequira, a small characid, approaching and biting individuals of larger-bodied fishes of other species. This observation was made in two clear water headwater streams of the Cuiabá basin, Paraguay River system, located in Nobres, Mato Grosso State, Brazil, which led us to investigate the behavioral interactions of these fish. We characterized behavioral interactions between species by direct underwater observations using snorkelling and video recordings. Additionally, we proceeded diet analyses of $O$. pequira, obtaining intestinal coefficient and the index of alimentary importance. During underwater observations we checked the relative frequency of attacks by $O$. pequira on larger fish species. Odontostilbe pequira attacked individually or in large groups, and the anostomid Leporinus friderici was the preferred target prey species, while Prochilodus lineatus was apparently avoided. Our study sustains that $O$. pequira is omnivorous, with a diet that varies seasonally. It feeds mainly on plants, but also on animal prey, including the scales of small fishes, and, possibly, the mucus and epidermis of larger fish species. We suggest the term "mutilating predation" to describe the latter relationship.

Observamos indivíduos de Odontostilbe pequira, um caracídeo pequeno, abordando e mordendo peixes maiores de outras espécies. Essa observação foi feita em dois riachos de cabeceira com águas cristalinas na bacia do rio Cuiabá, sistema do rio Paraguai, localizados em Nobres, Mato Grosso, Brasil, o que nos levou a investigar a interação comportamental desses peixes. Nós o fizemos através de observações subaquáticas diretas usando mergulho livre e vídeo. Adicionalmente, realizamos a análise da dieta de $O$. pequira, obtendo seu coeficiente intestinal e índice de importância alimentar. Nas observações subaquáticas avaliamos a frequência relativa dos ataques de $O$. pequira sobre peixes maiores. Odontostilbe pequira ataca individualmente ou em grupos grandes, o anostomídeo Leporinus friderici foi a presa preferida, enquanto Prochilodus lineatus foi evitado. Este estudo sustenta que $O$. pequira é um peixe onívoro cuja dieta varia sazonalmente. Ele come principalmente plantas, mas também presas animais, como escamas de peixes pequenos e, possivelmente, muco e epiderme de peixes maiores. Sugerimos o termo "predação mutilante" para descrever essa relação.

Key words: Animal behavior, Feeding plasticity, Lepidophagy, Underwater observations.

\section{Introduction}

Many fish species have markedly plastic diets (Abelha et al., 2001; Dabrowski \& Portella, 2005). The changes in their food may relate to the ontogeny (Santos et al., 2009), the supply of certain food within portions of their geographic distribution (Dias, 2007), or the seasonal availability of those items (Hahn et al., 1992; Ferretti et al., 1996).

Odontostilbe pequira, popularly known as pequira in western Brazil, is a small species (maximum length of $56 \mathrm{~mm}$,
Malabarba, 1998) of the order Characiformes (Characidae: Cheirodontinae) occurring in the La Plata River basin in Brazil, Paraguay and Argentina (Malabarba, 2003). Species of the subfamily Cheirodontinae are distributed through Central and South America (Malabarba, 2003).

Studies on the diet of $O$. pequira in different locations have suggested that it can be classified as an herbivore or omnivore based on the index of alimentary importance (IAi), depending on the study area. In macrophyte beds of the

\footnotetext{
${ }^{1}$ Universidade do Estado de Mato Grosso, Laboratório de Ecologia Comportamental da Reprodução, LECR, Câmpus de Tangará da Serra. Rodovia MT 358 km 7, Jardim Aeroporto, 78300-000 Tangará da Serra, MT, Brazil.

${ }^{2}$ Universidade Estadual Paulista “Júlio de Mesquita Filho",Instituto de Biociências, Letras e Ciências Exatas, Departamento de Zoologia e Botânica, Programa de Pós-Graduação em Biologia Animal. Rua Cristovão Colombo, 2265, Jardim Nazareth, 15054-000 São José do Rio Preto, SP, Brazil. prof.bessa@yahoo.com.br

${ }_{3}^{3}$ Universidade Federal do Paraná, Departamento de Zoologia, Setor de Ciências Biológicas, Programa de Pós-Graduação em Zoologia. Caixa Postal 19020, 81531-980 Curitiba, PR, Brazil. dioneskrinski@ibest.com.br

${ }^{4}$ Universidade Federal do Mato Grosso, Núcleo de Estudos de Biodiversidade da Amazônia Mato-Grossense (NEBAM), Instituto de Ciências Naturais, Humanas e Sociais (ICNHS). Câmpus Universitário de Sinop, Avenida Alexandre Ferronato, 1200, Setor Industrial, 78557-267 Sinop, MT, Brazil. carvalholn@yahoo.com.br
} 
Pantanal the species was described as herbivore (Santos et al., 2009); in reservoirs, it had an insectivorousherbivorous diet (Luz-Agostinho et al., 2006); in floodplain lakes along the Cuiabá River, O. pequira was described as an omnivore (Ximenes et al., 2011); finally, Dias (2007) described it as a detritivore-carnivore in the Ibicuí River, Rio Grande do Sul, Brazil. Thus, there is no consensus on the diet of this species, which seems to vary geographically due to plasticity.

Previous studies also revealed that scales were found in the digestive tract of $O$. pequira, although in small amounts (Dias, 2007; Santos et al., 2009). The presence of scales was attributed to accidental capture while feeding on benthic items (Dias, 2007). As part of this study, we sought to further investigate the possibility of lepidophagy, or non-facultative scale-eating, in $O$. pequira.

In the streams of Bom Jardim, Mato Grosso, Brazil, a large number of $O$. pequira was frequently seen biting larger fish. Co-occurring in these streams are many 'piraputangas' (Brycon hilarii), 'piau-três-pintas' (Leporinus friderici), 'curimbas' (Prochilodus lineatus) and 'dourados' (Salminus brasiliensis), among various other species. Fish approached by $O$. pequira often show signs of stress, such as changes in color (Rodrigues et al., 2009) and swimming pattern (Kanea et al., 2004). These observations raised the question as to what constitutes the diet and characterizes the feeding behavior of $O$. pequira, and its effects on other fish.

Our objective was to elucidate the feeding behavior and interactions between $O$. pequira and other local abundant fish species, including the anostomid Leporinus friderici, the characids Brycon hilarii, Salminus brasiliensis, and the prochilodontid Prochilodus lineatus. We used two approaches: (1) we made direct underwater observations of the feeding behavior of $O$. pequira and evaluated interspecific interactions relative to abundance of each of the targeted prey species; and (2) we studied the morphology and diet of $O$. pequira, to determine the intestinal coefficient and characterize the items by frequency, volume and alimentary importance of the ingested food. We conclude with a discussion of terminology employed to describe this type of behavioural interaction among fishes and the possible nutritional benefits associated with lepidophagy and muciphagy.

\section{Material and Methods}

\section{Study area}

The streams that flow through Bom Jardim, Mato Grosso State, Brazil, belong to the Paraguay basin, which forms the La Plata-Uruguay-Paraná-Paraguay system, which extends over an area of 3.2 million $\mathrm{km}^{2}$ (Lowe-McConnel, 1999). The Estivado and Salobra rivers are headwater tributaries of the rivers that form the Pantanal flood plains, flowing into the Cuiabá River. These streams have clear waters due to the deposition of the sediments caused by the calcium ions from the soil. Visibility often exceeds $40 \mathrm{~m}$.
Most observations were made in the Estivado River, in Bom Jardim, district of Nobres Municipality (14\% $43^{\prime} 13^{\prime \prime} \mathrm{S} 56^{\circ}$ 19'9'W) (Fig. 1). Additional observations were made in Salobra

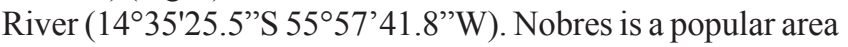
sought by tourists for fish-watching, due to its crystalline water streams.

\section{Underwater observations}

Daytime observations on the behaviour of Odontostilbe pequira were made in August and December 2009 in 15 sessions of up to $60 \mathrm{~min}$ each, within various sections of a 120-m reach of the Estivado River (Fig. 1). We used the sequence-sampling method, in which the focus is a behavioural sequence (Martin \& Bateson, 2007), in our case, the act of approaching other fish apparently aiming to feed on mucus and/or scales. We completed a total of $12.5 \mathrm{~h}$ of snorkelling, taking notes on an underwater writing slate. We also photographed and recorded the behavior on video, using a camera enclosed in a waterproof housing.

Additionally we observed the frequency with which $O$. pequira attacked each of the main target species (B. hilarii, L. priderici, $S$. brasiliensis, and $P$. lineatus) in ten sessions
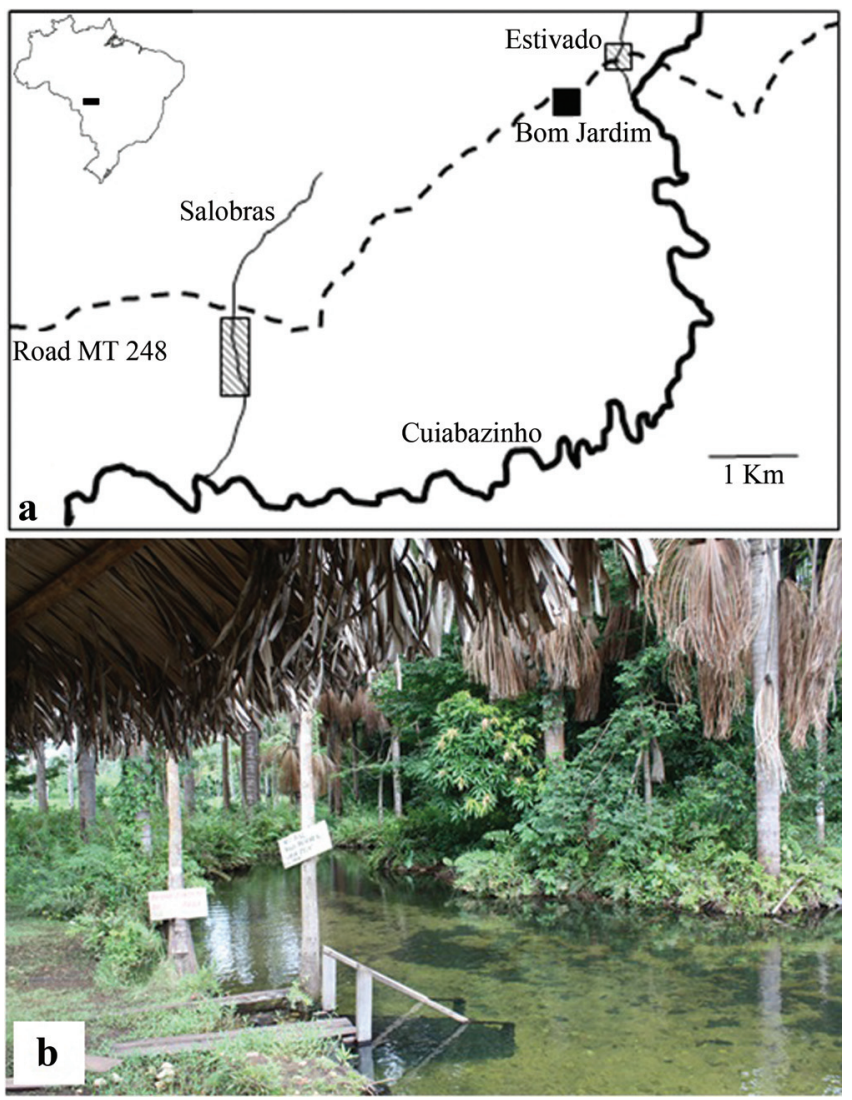

Fig.1. Study area. a) Detailed map of the study area, black rectangle on the map of Brazil indicates the location of Bom Jardim. Dashed areas indicate the main study area (Estivado River) and a comparison area (Salobra River). b) Photo of the study site in Estivado River by Eduardo Bessa (December 2009). 
of $15 \mathrm{~min}$ each, for each species. This data were used to infer the preference for a target fish species, combining the previous data with visual census of the target's abundance. The significance of the results was verified by a Chi-square test in which the frequency of attacks was the observed value and the target's abundance was the expected value, with $\alpha=0.05$. Ten censuses were made in different $10-\mathrm{m}$ reaches of the Estivado River with visibility of at least $6 \mathrm{~m}$. The reaches were measured with a meter tape and snorkelled at constant speed for $10 \mathrm{~min}$, thus evaluating an area of $10 \mathrm{~m}$ x $12 \mathrm{~m}$ (length of the transect times twice the visibility). Low standard deviation between counts allowed us to be more confident in this method for estimating populations; nevertheless, every visual method is limited, especially with larger schools and fastmoving fish (Labrosse et al., 2002). In order to avoid betweenobserver bias, all counts were made by the same observer.

\section{Diet Analysis}

For the diet analysis we used 30 specimens of $O$. pequira captured in August plus other 30 caught in December 2009. We captured fish with $70-\mathrm{cm}$ wide seines with $2.5 \mathrm{~mm}$ mesh, and $2 \mathrm{~L}$ fish traps made of PET plastic bottles. The traps were left amid the vegetation for $3 \mathrm{~h}$ baited with a mixture of cassava flour and sardine oil in a container that allowed the attractive odor to disperse, but prevented the fishes from eating the bait. Collected specimens were fixed in $10 \%$ formaline and preserved in $70 \%$ ethanol within three days. All the fishes, including $O$. pequira and the scale-bank fishes (see below), were identified with taxonomic keys (Britski et al., 2007) and the support of specialists. Voucher specimens of $O$. pequira are deposited in the Coleção de Peixes do Departamento de Zoologia e Botânica da Universidade Estadual Paulista, São José do Rio Preto (DZSJRP 14800).

Standard length (SL) and intestine length (IL) were measured to the nearest $\mathrm{mm}$. The intestinal coefficient (IC) was calculated for each individual as IC=SL/IL. We present here a mean value \pm standard deviation and the data range. The intestinal coefficient is indicative of a relationship between anatomy (intestine length and standard length) and the types of food consumed (Fugi \& Hahn, 1991). Stomach contents were examined under a stereomicroscope; food items were identified as algae, autochthonous insects, allochthonous insects, scales from other fishes, and plant debris. The scales were identified by comparison with a scale bank assembled from a reference collection of fishes from Bom Jardim. All scales were taken from the middle-body upper right flank of the fish, where most attacks occurred. Scale measures were taken from its shortest axis. This collection is housed at the Museu de Zoologia de Tangará da Serra, UNEMAT.

To measure the ingested volume of each item we used four $1 \mathrm{~mm}$-thick histological glass slides. Each food item was placed on the top of the slide that had a graph paper attached to the opposite side to serve as a counting grid; then the food item was compressed between two slides, and another slide was placed on the top to limit the height of the mass to
$1 \mathrm{~mm}$. Thus, counting the number of $1-\mathrm{mm}$ squares covered by the mass resulted in determination of each item's volume in $\mathrm{mm}^{3}$. When necessary an optical microscope was used to better visualize the material.

The diet was quantified using the index of alimentary importance (IAi), represented as the values for frequency of occurrence ( $\mathrm{Fi}$, number of stomachs that contained each item, in relation to the number of stomachs with food) and volume (Vi, volume occupied by each item), where IAi $=\mathrm{Fi} * \mathrm{Vi} / 100$ (Kawakami \& Vazzoler, 1980). Items with values of IAi higher than the mean of all items combined were considered important for the species.

\section{Results}

\section{Feeding behaviour}

Odontostibe pequira occurred in great abundance in Estivado River, and we visually estimated about 10,000 individuals in a $10 \mathrm{~m}$ stretch in December 2009, at the beginning of the rainy season. This species is a midwater dwelling fish that occurs in schools with other small-bodied species of Characiformes. It is more active at daylight, when individuals occupy slowly to moderately flowing stretches over sand, rock, or detritus-covered bottoms. At dusk individuals were found resting near the shoreline.

We observed that $O$. pequira approached larger fish in two ways: (1) individual attacks or (2) group attacks. When a larger fish (e.g. Leporinus friderici) was resting or swimming slowly, one $O$. pequira approached it swimming perpendicularly towards the target fish's flank, and contacted it with the mouth (Fig. 2). When doing so individually (1), the targeted fish quickly swam away. In the case of (2), a group of $O$. pequira advanced rapidly towards a target fish that was swimming away, and individuals then appeared to alternately take bites of exposed portions of the target fish. This behavior resulted in a trail of $O$. pequira following the target, analogous in appearance to a comet (Fig. 2c).

Many of the larger target fish remained motionless at the river bottom, a behavior that apparently reduced the chance of being approached by $O$. pequira. In these circumstances, only individual attacks occurred. Conversely, when a target fish wandered to forage, group attacks were more common. Targets of a group attack responded to the approach by swimming away rapidly or by performing erratic movements. Accelerated swimming occurred in straight-line bursts for about three seconds, occasionally being repeated if individuals of $O$. pequira still followed. Erratic swimming involved abrupt changes in swimming direction or tail snaps on the river bottom.

The species attacked more often was the anostomid Leporinus friderici; Brycon hilarii was second, with about half as many attacks as L. friderici, Salminus brasiliensis, and Prochilodus lineatus were the least attacked large fishes in the area (Fig. 3). Among the targeted fishes Leporinus friderici and $B$. hilarii were the most abundant species, followed by P. lineatus and then by $S$. brasiliensis (Fig. 4). Brycon hilarii and L. friderici spent more time near the 
stream bottom, and presented darker skin color pattern than their conspecifics from other rivers where fewer $O$. pequira were found, such as the Salobra River (Fig. 1). Chi-square test indicates that the 'pequiras' preferred attacking $L$. friderici and avoided $P$. lineatus $\left(\chi^{2}: 5.305 \times 10^{-5}\right.$, $\mathrm{df}=3, P=$ $\left.1,028 \times 10^{-7}\right)$. Leporinus friderici and $B$. hilarii were frequently seen with wounds on the flanks, the same region attacked by $O$. pequira.

\section{Diet analysis}

In our study $O$. pequira appears to be an opportunistic feeder with a plastic diet, i.e. characterised by having no specialisation for a specific food item. On many occasions ledidophagy was observed.

Individuals collected measured $31.6 \pm 1.6 \mathrm{~mm}$ in SL (mean \pm standard deviation; $\mathrm{N}=60$ ). Odontostilbe pequira's intestinal coefficient was $\mathrm{IC}=0.62 \pm 0.12$, ranging from 0.55
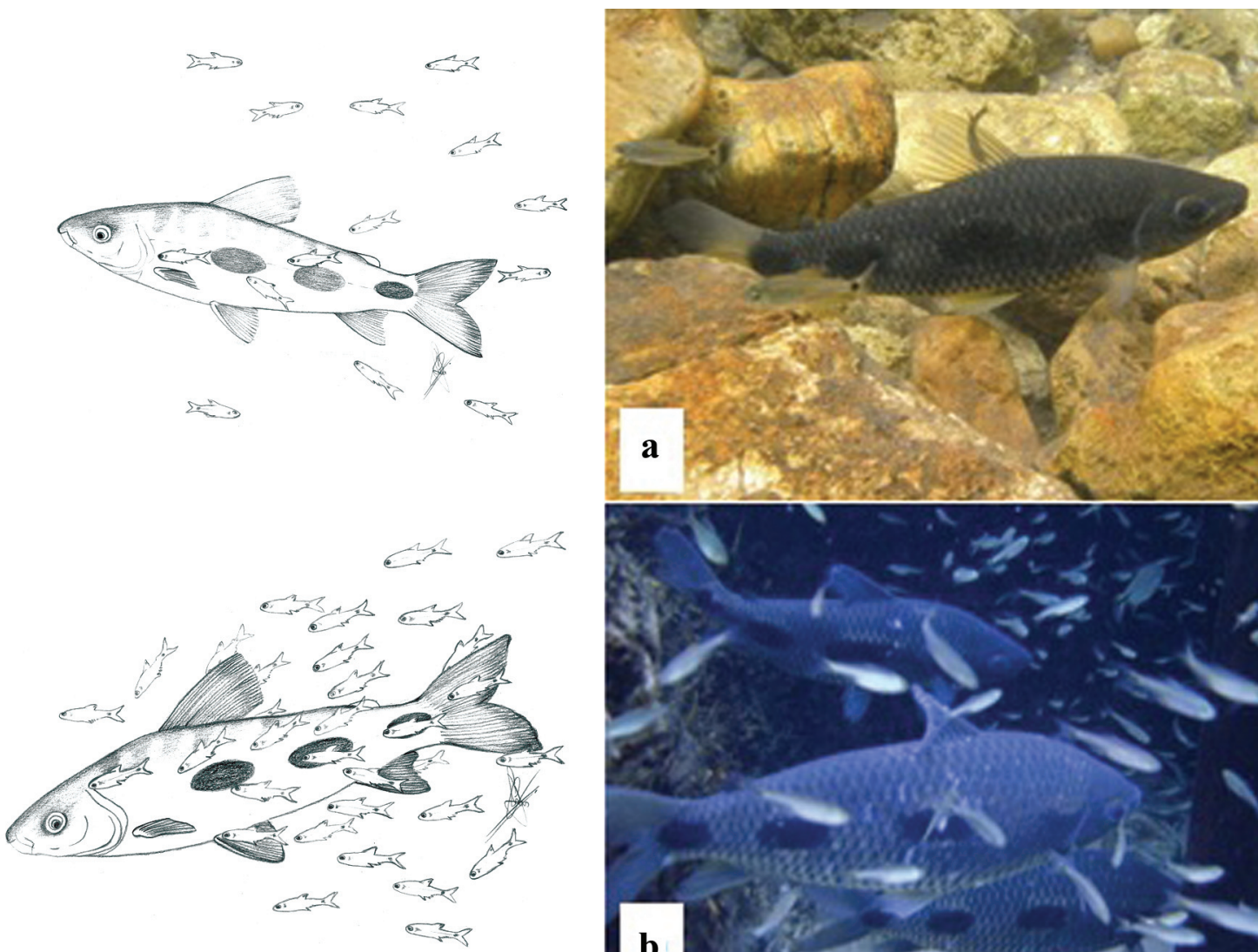

$\mathbf{a}$
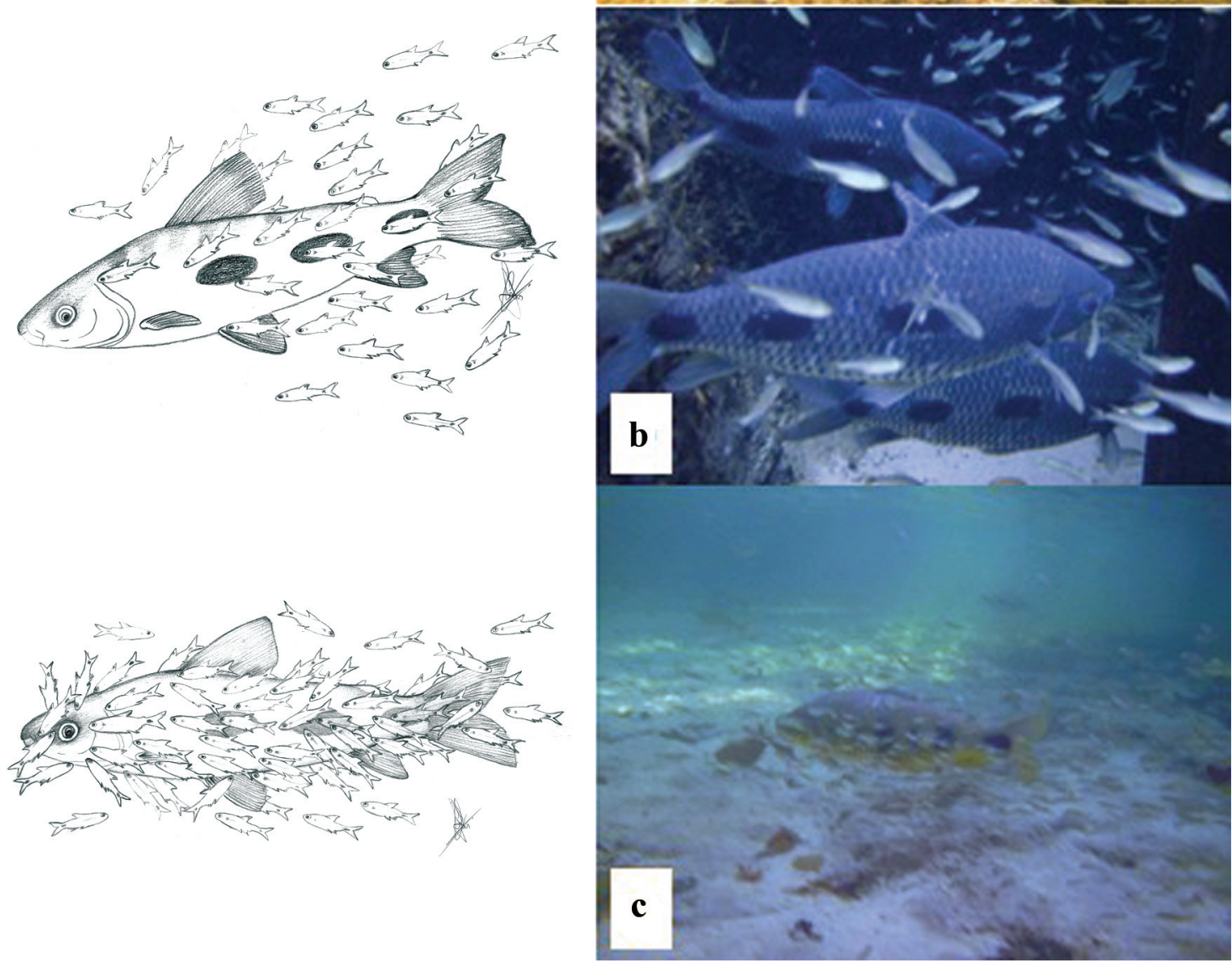

Fig. 2. Odontostilbe pequira attacks upon Leporinus friderici. a) individual attack; b) beginning of a group attack; and c) group of $O$. pequira in a group attack. Drawings by Cristiane Freitas; photo (a) by Lucélia Carvalho; (b) and (c) by Eduardo Bessa (August 2009). 


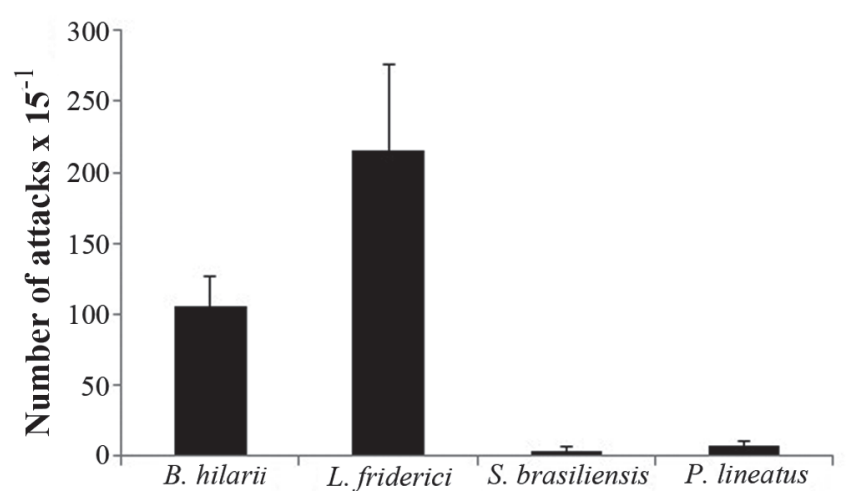

Fig. 3. Mean number ( $\pm \mathrm{SD}$ ) of attacks by Odontostilbe pequira towards larger fish during 15-min observation sessions of focal target species. $\mathrm{N}=10$.

to $1.29(\mathrm{~N}=60)$, which places the species within the range of omnivorous fishes.

Among food items ingested by $O$. pequira (Table 1), the most frequent were algae and plant debris. Fish scales, allochthonous and autochthonous insects were less frequent in the diet. Forty percent of the 60 individuals analysed were exclusively herbivores (algae and plant debris). The index of alimentary importance verified that algae was the most important food item of O. pequira in the Estivado River, followed by plant debris, autochthonous insects, scales, and allochthonous insects.

All stomachs examined from specimens collected in both the dry and rainy seasons contained food items. However, the importance of items varied between seasons (Table 1); plant debris was four times as important, and autochthonous insects were twice as important in the dry season than in the wet season. In contrast, scales and allochthonous insects were half as important in the dry season than in the wet season.

Fish scales were ingested by $23 \%$ of the individuals ( $F i$ for dry and rainy seasons summed) and totalled $8 \%$ of all the food ingested (Vi for both the seasons summed). Of the scales found in the stomach of O. pequira, none belonged to Brycon hilarii, Leporinus friderici, or Prochilodus lineatus, which measured $7.24 \pm 0.73 ; 8.37 \pm 0.57$; and $8.51 \pm 0.31 \mathrm{~mm}$, respectively ( $\mathrm{N}=6$ for each species). This scale size is wider than the gape of $O$. pequira, which averaged $2.12 \pm 0.34 \mathrm{~mm}$ $(\mathrm{N}=15)$. Comparing with the local reference scales bank, the ingested scales probably belonged to Hyphessobrycon

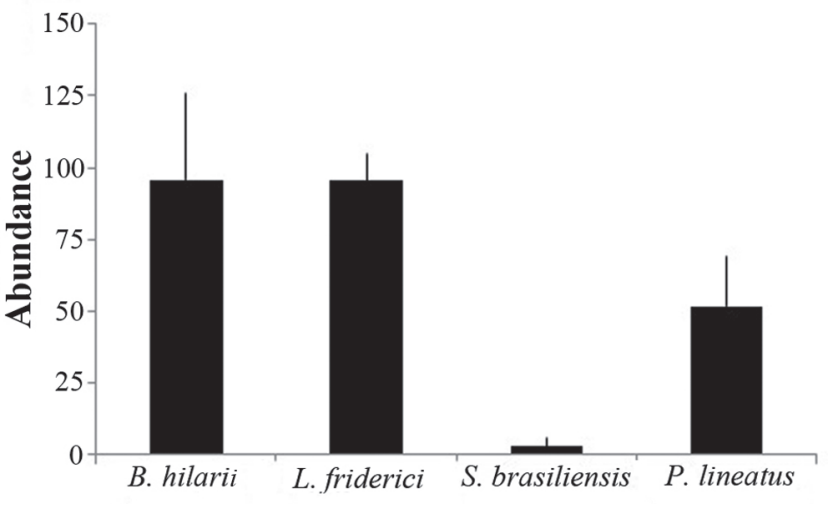

Fig. 4. Abundance of the main targets of Odontostilbe pequira. Mean number of individuals recorded in $10 \times 12 \mathrm{~m}$ area censuses \pm standard deviation. $\mathrm{N}=10$.

elachys, Astyanacinus moorii and Serrapinus microdon; which scales measured $1.23 \pm 0.27 \mathrm{~mm}$ (for the three above mentioned species combined; $\mathrm{N}=27$ ).

\section{Discussion}

Odontostilbe pequira attacked several kinds of fish, individually or in large groups. Despite being fundamentally herbivorous, $O$. pequira complemented its diet with scales. Although our method did not allow us to unequivocally determine if epidermis or mucus constitute a food item of $O$. pequira, these items are presumed to have some importance to this species' diet, as inferred by its behavior towards target species.

Many piscivorous species attack their targeted preys in groups (Keenleyside, 1974; Sazima \& Machado, 1990), as observed in our study. Some mathematical models of predation have shown that attacks on prey species with a larger body size than the predator's are generally made in groups, except when the prey is caught unaware or resting (Mchicha et al., 2006). This was consistent with our observations of attacks by $O$. pequira on larger fish.

Fish that were targeted by attacks from $O$. pequira exhibited different strategies for avoiding attacks. Their response included attempts to outswim attackers (straight line burst), foil them (erratic swimming), or avoid being perceived by potential attackers (staying still by the bottom or in crevices), somewhat analogous to strategies known in artiodactyle mammals (Caro et al., 2004).

Table 1. Seasonal variation in the diet of Odontostilbe pequira. Fi\%: frequency of occurrence; Vi\%: volume; IAi: index of alimentary importance.

\begin{tabular}{|c|c|c|c|c|c|c|}
\hline \multirow[t]{2}{*}{ Food items } & \multicolumn{2}{|c|}{$\mathrm{Fi} \%$} & \multicolumn{2}{|c|}{$\mathrm{Vi} \%$} & \multicolumn{2}{|c|}{ IAi } \\
\hline & Rainy & Dry & Rainy & Dry & Rainy & Dry \\
\hline Algae & 0.967 & 0.733 & 51.320 & 91.980 & 0.496 & 0.674 \\
\hline Plant debris & 0.567 & 0.767 & 16.950 & 63.110 & 0.0961 & 0.484 \\
\hline Fish scales & 0.430 & 0.100 & 2.160 & 0.440 & 0.009 & 0.000 \\
\hline Allochthonous insects & 0.233 & 0.100 & 2.680 & 0.210 & 0.006 & 0.000 \\
\hline Autochthonous insects & 0.333 & 0.200 & 6.150 & 22.10 & 0.020 & 0.044 \\
\hline
\end{tabular}


Lepidophagy and muciphagy result in negative consequences for the fish attacked, like the wounds we observed in Estivado River. Lepidophagy exposes internal tissues and increases the chances of infection (Fontenot \& Neiffer, 2004). Fish mucus is known to function in immune defense, osmotic balance, and hydrodynamics (Ebran et al., 1999). The loss of both, scales and mucus, may reduce the health of the target species and may, therefore, lower their population abundance (Piana et al., 2006).

The number of attacks did not appear to correlate with the abundance of the targeted species; i. e. O. pequira showed a preference for $L$. friderici and avoided P. lineatus. This may be due to the slower swimming speed of the species (Britski et al., 2007), or to the mucus volume or its different nutritional value (Grutter \& Bshary, 2004).

The intestinal coefficient of a fish indicates how the intestinal length relates to the nutritional value of the food items that it consumes (Seixas-Filho et al., 2000). Fish that feeds on items resistant to digestion, such as plant matter or algae, must have longer intestines. Odontostilbe pequira possess an intestine of intermediate length (IC = 0.62 ), which combined to its diet composition allows to characterise it as an omnivore with a tendency to herbivory (sensu Bértin, 1958).

Odontostilbe pequira was also described as an omnivore with a tendency to herbivory by Fugi \& Hahn (1991). This species is plastic in its diet, taking advantage of different food sources along the year, which is common in many tropical fishes (Dias, 2007). According to Shibatta et al. (2002), feeding plasticity is characteristic of some species that are subjected to environmental variations that result in shifts in the availability of food items. The Estivado River is under seasonal variations due to the cyclical nature of weather in the Brazilian savannah (Ab'Sáber, 2003).

The diet documented herein for Odontostilbe pequira from the Estivado River did not differ markedly from that found in other studies, although the relative importance of the different food items varies. Oliveira (2003) found that an unidentified species of the genus Odontostilbe fed on algae, plant matter, insects, and small fish. Dias (2007) studied eight species of the subfamily Cheirodontinae, including $O$. pequira, and found a similar diet for this species as we observed, including algae, plant matter, insects, and fish scales.

Lowe-McConnell (1999) concluded that in tropical ecosystems fishes depend primarily on allochthonous material, mainly in the rainy months when this kind of material is washed into the rivers in large quantities. This was the case in our study, in which allochthonous items, such as adult insects, were more common in the rainy season, and autochthonous items, such as algae and insect nymphs, were ingested more often during the dry season. The increase in scale eating in the rainy season may have been related to an increase in the density of the targeted prey species in the Estivado River. Francisco (2004) noted that if availability of certain food items changed throughout the year, fish tend to be opportunistic and changed the diets relative to their availability.
Underwater observations of the behaviour of $O$. pequira in the Estivado River indicates that this species consumed scales and, possibly, also the epidermis and mucus of targeted fish, as already noted in other studies (Dias, 2007; Santos et al., 2009). Although our methods could not confirm the ingestion of mucus or epidermic tissue, we speculate that these items were part of the diet in the population of $O$. pequira that we studied. Histological preparations of the gastrointestinal tract stained with Luna's Alcian Blue can indicate the consumption of mucus (Winemiller \& Yan, 1989), but only when mucus occur in large amounts, which was not the case in our study.

Scale and/or mucus eating may provide valuable nutrients to $O$. pequira. Lepidophagy offers proteins and minerals (Géry $\&$ Vieira, 1979), mainly from the epidermis that covers the scales. Muciphagy provides an abundant and renewable source of amino acids and sugars (Ebran et al., 1999). It is also possible that ingesting mucus brings immune protection (Buckley et al., 2010). The South American catfish Ochmacanthus alternus was described as specialised in muciphagy (Winemiller \& Yan, 1989), but other cases of occasional ingestion of this resource are known to benefit fry by species that exhibit parental care (Buckley et al., 2010), as well as species that exhibit cleaning behavior (Grutter \& Bshary, 2004). The Estivado River is an oligotrophic environment, and in times of seasonal food limitation and possible competition for food, it is possible that such alternative feeding habit benefits to $O$. pequira.

There is no consensus of how to define lepidophagy, since differentiating between predation and parasitism itself may be considered merely a matter of recognizing categories within a continuum of feeding strategies (Allaby, 2009). Some authors have categorized lepidophagy as a parasitic habit (Keenleyside, 1979; Wootton, 1998), whereas others have considered it to be a type of predation (Sazima, 1977; Grubh \& Winemiller, 2004). Parasitism is typically defined as the relationship in which one species, the parasite, takes nutrients and residency from another, the host, in a close and lasting association that seldom leads to direct death of the host (Zelmer, 1998). Predation, on the other hand, may be defined broadly, and may include the definition of parasitism, in which one species is benefited and the other is harmed (Abrams, 1987), or, narrowly, as the interaction between two species in which one of them, the predator, gains energy by killing and consuming the other, the prey (Pollard, 1992). None of the above definitions adequately describes the relationship between $O$. pequira and the large fish that it attacks. Herein we consider lepidophagy as a mutilating predation of the targeted species upon which it preys. The term was not introduced by us, Sazima \& Pombal-Jr. (1988) described finclipping as a mutilating predation. We define mutilating predation as an association in which the predator consumes parts of its prey in a brief encounter, the consequences of which appears to have little chance of killing the victim.

Odontostilbe pequira is an omnivore, feeding mainly on plants, but also on animal items. Its diet varies seasonally 
and it consumes small fish scales and, possibly, the mucus and epidermis of larger fish; of the later in this study, most frequently Leporinus friderici. Future studies of captive specimens are needed to fully evaluate how larger species are affected, if at all, by predation on them by $O$. pequira.

\section{Acknowledgements}

This study was funded by the Fundação de Amparo à Pesquisa do Mato Grosso, FAPEMAT (Process number 002.191/2007). We thank Mrs. Joana Lambert, Messrs K. Oliveira, Antônio Campos, and Isaías de Almeida for the access to the study sites. Species identification was aided by Waldo P. Troy and Francisco Langeani, for which we are grateful. We also thank Fabrício B. Teresa, Raoni Rodrigues, and Domingos G. Neto for their critical reviews of this manuscript. This text was greatly improved by the valuable suggestions of S. J. Walsh and those of Janet Reid on language and style.

\section{Literature Cited}

Ab'Sáber, A. 2003. Os domínios de natureza no Brasil, potencialidades paisagísticas. São Paulo, Ateliê Editorial, 159p.

Abelha, M. C. F., A. A. Agostinho \& E. Goulart. 2001. Plasticidade trófica em peixes de água doce. Acta Scientiarum, 23: 425-434.

Abrams, P. A. 1987. On classifying interactions between populations. Oecologia, 73: 272-281.

Allaby, M. 2009. Oxford dictionary of Zoology. Oxford, Oxford University Press, 704p.

Bértin, L. 1958. Appareil digestif. Pp. 1249-1301. In: Grassé, P. P. (Ed.). Traité de Zoologie Tôme XIII. Paris, Masson, 2396p.

Britski, H. A., K. Z. S. Silimon \& B. S. Lopes. 2007. Peixes do Pantanal. Second Edition. Brasília, EMBRAPA, 2nd Edition, 230p.

Buckley, J., R. J. Maunder, A. Foey, J. Pearce, A. L. Val \& K. A. Sloman. 2010. Biparental mucus feeding: a unique example of parental care in an Amazonian cichlid. Journal of Experimental Biology, 213: 3787-3795.

Bührnhein, C. M. 2006.Sistemática de Odontostilbe Cope, 1870 com a proposição de uma nova tribo Odontostilbini e redefinição dos gêneros incertae sedis de Cheirodontinae (Ostariophysi: Characiformes: Characidae). Unpublished Ph.D. Dissertation, Pontifícia Universidade Católica do Rio Grande do Sul, Porto Alegre, 322p.

Caro, T. M., C. M. Graham, C. J. Stoner \& J. K. Vargas. 2004. Adaptive significance of antipredator behaviour in artiodactyls. Animal Behaviour, 67: 205-228.

Dabrowski, K. \& M. C. Portella. 2005. Feeding plasticity and nutritional physiology in tropical fishes. Pp. 155-209. In: A. Val; V. M. F. Almeida-Val \& D. Randall (Eds.). Fish physiology volume 21. Amsterdam, Elsevier, 400p.

Dias, T. S. 2007. Estudo da dieta de oito espécies da subfamília Cheirodontinae (Characiformes: Characidae) em diferentes sistemas lacustres nos estados do Rio Grande do Norte e Rio Grande do Sul. Unpublished M.Sc. Dissertation, Universidade Federal do Rio Grande do Sul, Porto Alegre, 89p.

Ebran, N., S. Julien, N. Orange, P. Saglio, C. Lemaitre \& G. Molle. 1999. Pore-forming properties and antibacterial activity of proteins extracted from epidermal mucus of fish. Comparative Biochemistry and Physiology Part A, 122: 181-189.
Ferretti, C. M. L., I. F. Andrian \& G. Torrente. 1996. Dieta de duas espécies de Schizodon (Characiformes, Anostomidae) na planície do alto rio Paraná e sua relação com aspectos morfológicos. Boletim do Instituto de Pesca, 23: 171-86.

Fontenot, D. K. \& D. L. Neiffer. 2004. Wound management in teleost fish: biology of the healing process, evaluation, and treatment. Veterinary Clinic of Exotic Animals, 7: 57-86.

Francisco, C. A. C. 2004. Rede de Kohonem: Uma ferramenta no estudo das relações tróficas entre espécies de peixes. Unpublished M.Sc. Dissertation, Universidade Federal do Paraná, Curitiba, 126p.

Fugi, R. \& N. S. Hahn. 1991. Espectro alimentar e relações morfológicas com o aparelho digestivo de três espécies de peixes comedores de fundo do rio Paraná, Brasil. Revista Brasileira de Biologia, 51: 873-879.

Géry, J. \& I. Vieira. 1979. Crescimento diferencial e nutrição em Catoprion mento (Characoidei). Peixe lepidófago da Amazônia. Acta Amazonica, 9: 143-146.

Grubh, A. R. \& K. O. Winemiller. 2004. Ontogeny of Scale Feeding in the Asian Glassfish, Chanda nama (Ambassidae). Copeia, 2004: 903-907.

Grutter, A. S. \& R. Bshary. 2004. Cleaner fish, Labroides dimidiatus, diet preferences for different types of mucus and parasitic gnathiid isopods. Animal Behaviour, 68: 583-588.

Hahn, N. S., A. Monfredino Jr., R. Fugi \& A. A. Agostinho. 1992. Aspectos da alimentação do armado, Pterodoras granulosus (Ostariophysi, Doradidae) em distintos ambientes do rio Paraná. Revista UNIMAR, 14: 163-176.

Kane, A. S., J. D. Salierno, G. T. Gipson, T. C. A. Molteno \& C. Hunter. 2004. A video-based movement analysis system to quantify behavioral stress responses of fish. Water Research, 38: 3993-4001.

Kawakami, E. \& G. Vazzoler. 1980. Método gráfico e estimativa de índice alimentar aplicado no estudo de alimentação de peixes. Boletim do Instituto Oceanográfico, São Paulo, 29: 205-207.

Keenleyside, M. H. A. 1979. Diversity and adaptation in fish behaviour. Berlin, Springer-Verlag, 208p.

Labrosse, P., M. Kulbicki \& J. Ferraris. 2002. Underwater visual census survey, proper use and implementation. Secretariat of the Pacific Community, 60p.

Lowe-McConnell, R. H. 1999. Estudos ecológicos de comunidades de peixes tropicais. São Paulo, EDUSP, 534p.

Luz-Agostinho, K. D. G., L. M. Bini, R. Fugi, A. A. Agostinho \& H. F. Júlio Jr. 2006. Food spectrum and trophic structure of the ichthyofauna of Corumbá reservoir, Paraná River Basin, Brazil. Neotropical Ichthyology, 4: 61-68.

Malabarba, L. R. 1998. Monophyly of the Cheirodontinae, Characters and major clades (Ostariophysi: Characidae). Pp. 193-233. In: L. R. Malabarba, R. E. Reis, R. P. Vari, Z. M. S. Lucena \& C. A. S. Lucena (Eds.). Phylogeny and Classification of Neotropical Fishes. Porto Alegre, EDIPUCRS, 603p.

Malabarba, L. R. 2003. Subfamily Cheirodontinae (Characins, tetras). p. 215-221. In R. E. Reis, S. O. Kullander \& C. J. Ferraris Jr. (Eds.). Checklist of the Freshwater Fishes of South and Central America. Porto Alegre, EDIPUCRS, 729p.

Martin, P. \& P. Bateson. 2007. Measuring Behaviour, An Introductory Guide. Third edition. Cambridge, Cambridge University Press, 176p.

Mchicha, R., P. Auger \& C. Lett. 2006. Effects of aggregative and solitary individual behaviors on the dynamics of predator-prey game models. Ecological Modelling, 197: 281-289. 
Oliveira, C. L. C. 2003. Análise comparada de caracteres reprodutivos e da glândula branquial de duas espécies de Cherodontinae (Teleostei: Characiadae). Unpublished MSc. Dissertation, Universidade Federal do Rio Grande do Sul, Porto Alegre. 80p.

Piana, P. A., L. C. Gomes \& A. A. Agostinho. 2006. Comparison of predator-prey interaction models for fish assemblages from the neotropical region. Ecological Modelling, 192: 259-270.

Pollard, A. J. 1992. The importance of deterrence: Responses of grazing animals to plant variations. Pp. 216-239. In: R. S. Fritz \& E. L. Simms (Eds.). Plant Resistance to Herbivores: Ecology, Evolution and Genetics. University of Chicago Press, Chicago, $600 \mathrm{p}$.

Rodrigues, R. R., L. N. Carvalho, J. Zuanon \& K. Del-Claro. 2009. Color changing and behavioral context in the Amazonian Dwarf Cichlid Apistogramma hippolytae (Perciformes). Neotropical Ichthyology, 7: 641-646.

Santos, C. L., I. A. Santos \& C. J. Silva. 2009. Ecologia trófica de peixes ocorrentes em bancos de macrófitas aquáticas na baia Caiçara, Pantanal Mato-Grossense. Revista Brasileira de Biociências, 7: 473-476.

Sazima, I. 1977. Possible case of aggressive mimicry in a neotropical scale-eating fish. Nature, 270: 510-512.

Sazima, I. \& F. A. Machado. 1990. Underwater observations of piranhas in western Brazil. Environmental Biology of Fishes, 28: $17-31$.

Sazima, I. \& Pombal-Jr., J. P. 1988. Mutilação de nadadeiras em acarás, Geophagus brasiliensis, por piranhas, Serrasalmus spilopleura. Revista Brasileira de Biologia, 48: 477-483.
Seixas-Filho, J. T., J. M. Brás, A. T. M. Gomide, M. G. A. Oliveira \& J. L. D. E. Menin. 2000. Anatomia Funcional e Morfometria do Intestino no Teleostei (Pisces) de Água Doce Surubim (Pseudoplatystoma coruscans - Agassiz, 1829). Revista Brasileira de Zootecnia, 29: 1670-1680.

Shibatta, O. A., M. L. Orsi, S. T. Bennemann \& A. T. Silva-Souza. 2002. Diversidade e distribuição de peixes na bacia do rio Tibagi. Pp. 399-419. In: M. E. Medri, E. Bianchini; O. A. Shibatta \& J. A. Pimenta (Eds.). A Bacia do Rio Tibagi. Londrina, M. E. Medri, 595p.

Winemiller, K. O. \& K. H. Yan. 1989. Obligate mucus-feeding in a South American Trichomycterid catfish (Pisces: Ostariophysi). Copeia, 1989: 511-514.

Wootton, R. J. 1998. Ecology of Teleost Fishes. Dordrecht, Kluwer Academic Publishers. 389p.

Ximenes, L. Q. L., L. A. F. Mateus \& J. M. F. Penha. 2011. Variação temporal e espacial na composição de guildas alimentares da ictiofauna em lagoas marginais do Rio Cuiabá, Pantanal Norte. Biota Neotropica, 11: 1-11.

Zelmer, D. A. 1998. An evolutionary definition of parasitism. International Journal for Parasitology, 28: 531-533.

Submitted November 28, 2011

Accepted May 5, 2012

Published June 29, 2012 